Article

\title{
Synthesis of Triptorelin Lactate Catalyzed by Lipase in Organic Media
}

\author{
Hong Zhuang ${ }^{1}$, Zhi Wang ${ }^{2}$, Jiaxin Wang ${ }^{2}$, Hong Zhang ${ }^{2,3}$, Erna Xun ${ }^{2}$, Ge Chen ${ }^{2}$, Hong Yue ${ }^{2}$, \\ Ning Tang ${ }^{1}$ and Lei Wang ${ }^{2, *}$
}

1 Department of Food Science and Engineering, Jilin University, Changchun 130021, China; E-Mails: Zhuanghong@jlu.edu.cn (H.Z.); downingjlu@gmail.com (N.T.)

2 Key Laboratory for Molecular Enzymology and Engineering of Ministry of Education, College of Life Science, Jilin University, Changchun 130021, China; E-Mails: wangzhi@jlu.edu.cn (Z.W.); jiaxin1012@163.com (J.W.); Zhanghong163163@163.com(H.Z.); xunerna86@163.com (E.X.); chengeilm4196@gmail.com (G.C.); xinqingtianlan@sina.cn (H.Y.)

3 College of Chemistry, Jilin University, Changchun 130023, China

* Author to whom correspondence should be addressed; E-Mail: w_lei@jlu.edu.cn; Tel.: +86-431-85155247; Fax: +86-431-88980440.

Received: 23 May 2012; in revised form: 30 June 2012 / Accepted: 2 August 2012 / Published: 10 August 2012

\begin{abstract}
Triptorelin lactate was successfully synthesized by porcine pancreatic lipase (PPL) in organic solvents. The effects of acyl donor, substrate ratio, organic solvent, temperature, and water activity were investigated. Under the optimum conditions, a yield of $30 \%$ for its ester could be achieved in the reaction for about $48 \mathrm{~h}$.
\end{abstract}

Keywords: triptorelin lactate; lipase; enzyme activity; esterification

\section{Introduction}

Peptides play important roles in the pharmaceutical and food fields [1-5]. It is generally believed that modification of a peptide can expand its scope of application. It can enhance the oral absorption of peptides and increase their enzymatic stability [6]. It can also facilitate the interaction between the peptide and its binding sites on the cell membrane, and promote a depot effect through binding to plasma proteins and the local administration site [7]. 
The use of enzymes for the modification of peptides has been investigated in the past decades. For example, Sih and co-workers [8-10] investigated the use of oxidative enzymes (horseradish peroxidase and chloroperoxidase) on tyrosine-containing peptides to support the synthesis of natural macrocyclic peptides. Klaus et al. [11] investigated the important application of carboxypeptidase Y (CPD-Y) in the modification of peptides and found that CPD-Y could catalyze the exchange of the $C$-terminal amino acid residue in peptides with various other groups (for example, conversion of peptides to peptide esters, conversion of peptides to peptide amides or conversion of peptides to other peptides). The advantages of enzymatic peptide modification are freedom from racemization, minimal activation and side-chain protection, mild reaction conditions, high regio- and stereoselectivity. Furthermore, the reactions can be carried out in a mixture of organic solvent and water, devoid of the problem of low solubility of protected peptides in the organic solvents employed in chemical synthesis.

Lipases are the most commonly used enzymes in industrial processes. They can catalyze the acylation of peptides in organic solvents. Acylation of the peptide might affect its functions, including its stability, DNA binding, protein-protein interaction, and peptide-receptor recognition. However, there still remains relatively little research so far on the applications of lipase in the modification of peptides. Herein, we report a facile lipase-catalyzed acylation of a serine-containing peptide (triptorelin) in organic media (Scheme 1), whereby the reaction conditions for the acylation have been optimized.

Scheme 1. Synthesis of triptorelin lactate catalyzed by lipase.

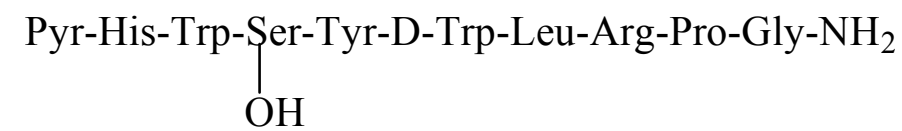

triptorelin<smiles>[C+]C(O)C(=O)O</smiles>

lactic acid

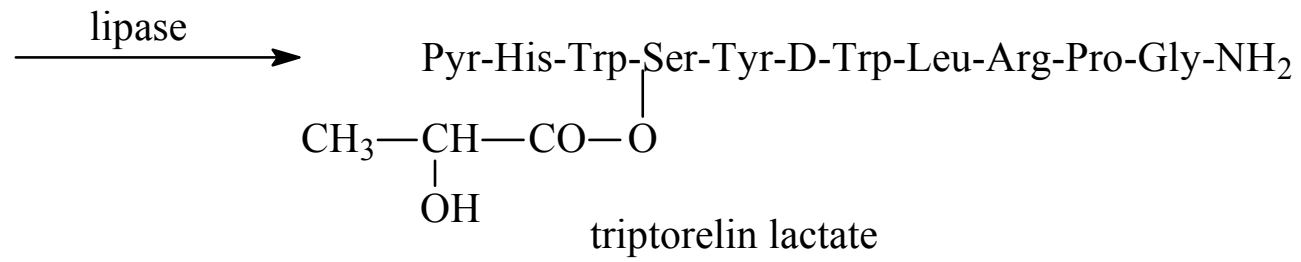

\section{Results and Discussion}

\subsection{Effect of Lipase Resource}

The catalytic reaction of lipase depended mainly on the type and origin of the enzyme [12]. Six commercially available lipases from various sources were selected as the catalysts for this study (Table 1). It was found that all the selected lipases could catalyze the esterification of triptorelin, but exhibited various enzyme activities. The different performances of the used lipases for esterification of triptorelin may be ascribed to their substrate specificity [13]. Because porcine pancreatic lipase (PPL) exhibited the highest activity $(2.25 \mu \mathrm{mol} / \mathrm{h} / \mathrm{g})$, it was selected as the catalyst for the next study. 
Table 1. Effect of lipase resource on the esterification of triptorelin *.

\begin{tabular}{ccccccc}
\hline Lipase & $\begin{array}{c}\text { Porcine } \\
\text { pancreatic } \\
\text { lipase (PPL) }\end{array}$ & $\begin{array}{c}\text { Pseudomonas } \\
\text { sp. (PSL) }\end{array}$ & $\begin{array}{c}\text { Pseudomonas } \\
\text { fluorescens lipase } \\
\text { (Lipase AK, AKL) }\end{array}$ & $\begin{array}{c}\text { Candida } \\
\text { cylindracea A.Y. } \\
\text { lipase (AYL) }\end{array}$ & $\begin{array}{c}\text { Candida } \\
\text { rugosa } \\
\text { lipase (CRL) }\end{array}$ & $\begin{array}{c}\text { Novozyme } \\
\mathbf{4 3 5}\end{array}$ \\
\hline Activity $(\mu \mathrm{mol} / \mathrm{h} / \mathrm{g})$ & 2.25 & 0.67 & 1.32 & 0.54 & 0.27 & 1.47 \\
\hline$*$ The reactions & were carried & out under the following conditions: & benzene $(1.0$ & $\mathrm{mL}$, & $\left.a_{\mathrm{w}}=0.51\right)$, \\
triptorelin $(1 \mu \mathrm{mol})$, lactic acid $(100 \mu \mathrm{mol})$ and lipase $(5.0 \mathrm{mg})$ at $40{ }^{\circ} \mathrm{C}$. & &
\end{tabular}

\subsection{Effect of Substrate Molar Ratio}

The rate of an enzymatic catalytic reaction also depends on the concentrations of the substrate [14]. In this study, the effect of the mole ratio of lactic acid to triptorelin from 1:1 to 200:1 on esterification was investigated when the amount of the enzyme and triptorelin were kept constant (Figure 1). It was found that the enzyme activity gradually increased with increasing substrate ratio. And a ratio of 100:1 turned out to be sufficient because the enzyme activity could not be improved after this point.

Figure 1. Effect of substrate ratio on the activity $(\mu \mathrm{mol} / \mathrm{h} / \mathrm{g})$ of PPL in esterification of triptorelin. The reaction flask contained benzene $\left(1.0 \mathrm{~mL}, a_{\mathrm{w}}=0.51\right)$, triptorelin $(1 \mu \mathrm{mol})$, porcine pancreatic lipase (PPL) $(5.0 \mathrm{mg})$. The reaction was performed at $40{ }^{\circ} \mathrm{C}$ and $150 \mathrm{rpm}$ with different substrate ratios (lactic acid: triptorelin $=1: 1-200: 1$ ).

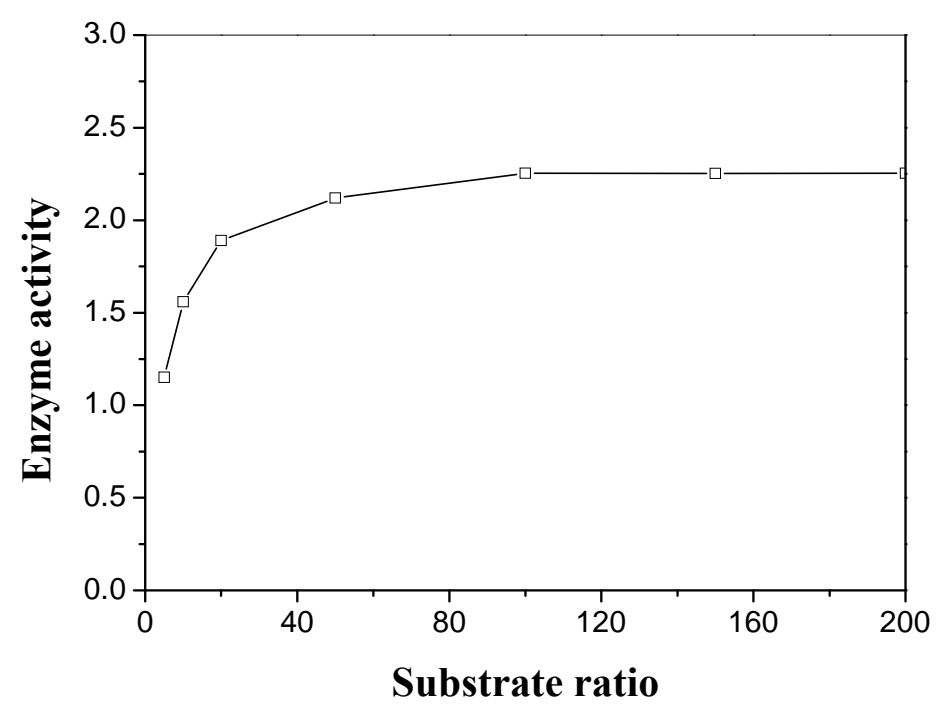

\subsection{Effect of Organic Media}

Various organic solvents with different $\log P(\log P$ [15], logarithm of the partition coefficient of a given solvent between $n$-octanol and water) were selected to investigate the effect of the reaction media. $\log P$ is the most frequently used parameter to denote the polarity or hydrophobicity of a solvent. As shown in Table 2, the highest enzyme activity was achieved when benzene was used as reaction medium. High polar solvent may strip off the essential water from the protein and disrupt the functional structure of the enzyme, which may decrease the enzyme activity [16]. The poor solubility of triptorelin in most of the selected organic solvents may also decrease enzyme activity. Furthermore, 
some organic solvent molecules might alter the enzyme conformation by penetrating into the enzyme active center and then changing enzyme performance [17].

Table 2. Effect of organic solvents on the esterification of triptorelin catalyzed by PPL * .

\begin{tabular}{ccc}
\hline Organic solvents & Log $\boldsymbol{P}$ & Enzyme activity $(\boldsymbol{\mu m o l} / \mathbf{h} / \mathbf{g})$ \\
\hline Dichloromethane & 1.25 & 1.75 \\
Benzene & 2.0 & 2.25 \\
Toluene & 2.5 & 1.95 \\
Cyclohexane & 3.2 & 1.87 \\
$n$-hexane & 3.5 & 1.45 \\
n-Heptane & 4.0 & 0.88 \\
Isooctane & 4.5 & 0.33 \\
\hline
\end{tabular}

* The reactions were carried out under the following conditions: different organic solvents $(1.0 \mathrm{~mL}$, $\left.a_{\mathrm{w}}=0.51\right)$, with triptorelin $(1 \mu \mathrm{mol}), \operatorname{PPL}(5.0 \mathrm{mg})$ and lactic acid $(100 \mu \mathrm{mol})$ at $40{ }^{\circ} \mathrm{C}$.

\subsection{Effect of Temperature}

Various temperatures were selected to examine the temperature effect on the activity of PPL in the esterification of triptorelin. As shown in Figure 2, the enzyme activity increased obviously as the reaction temperature increased from $20{ }^{\circ} \mathrm{C}$ to $40{ }^{\circ} \mathrm{C}$. The maximal enzyme activity was obtained at $40{ }^{\circ} \mathrm{C}$, then it decreased marginally with further increasing temperatures.

Figure 2. Effect of temperature on the activity $(\mu \mathrm{mol} / \mathrm{h} / \mathrm{g}$ ) of PPL in esterification of triptorelin. The reaction flask contained benzene $\left(1.0 \mathrm{~mL}, a_{\mathrm{w}}=0.51\right)$, triptorelin $(1 \mu \mathrm{mol})$, lactic acid $(100 \mu \mathrm{mol})$ and PPL $(5.0 \mathrm{mg})$. The reaction was performed at various temperatures $\left(20-60{ }^{\circ} \mathrm{C}\right)$ and $150 \mathrm{rpm}$.

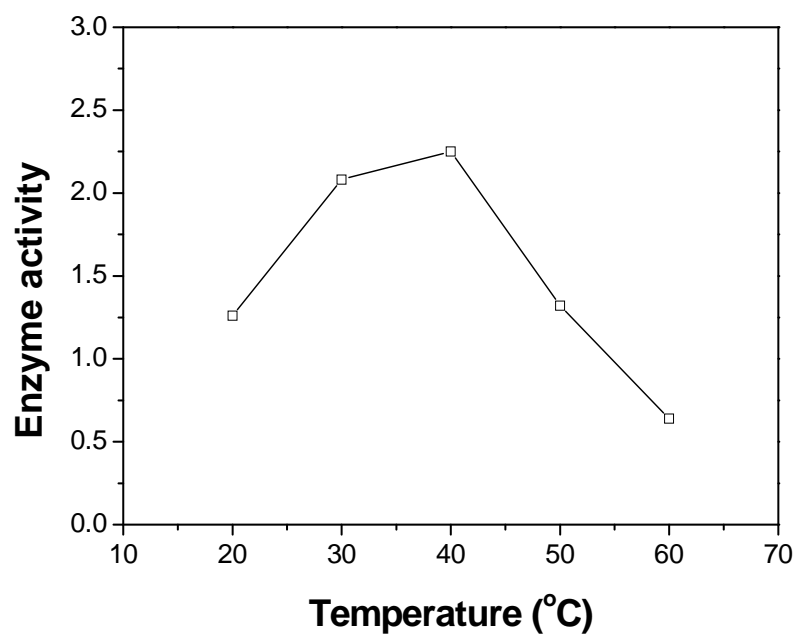

\subsection{Effect of Initial Water Activity}

One of the most important factors, which may affect the enzyme behavior in nonaqueous media is the water activity [18]. In the present study, the esterification catalyzed by PPL was conducted at a wide range of initial $a_{w}$ values (0.04-0.95). As can be observed in Figure 3, the enzyme activity exhibits a bell-shaped curve with changing water activity, and PPL exhibits the highest activity when 
$a_{w}=0.51$. Further decrease or increase in the initial $a_{w}$ value resulted in an obvious decrease in enzyme activity.

Figure 3. Effect of $a_{\mathrm{w}}$ on the activity ( $\mu \mathrm{mol} / \mathrm{h} / \mathrm{g}$ ) of PPL in esterification of triptorelin. The reaction flask contained benzene $\left(1.0 \mathrm{~mL}, a_{\mathrm{w}}=0.04-0.95\right)$, triptorelin $(1 \mu \mathrm{mol})$, lactic acid $(100 \mu \mathrm{mol})$ and PPL $(5.0 \mathrm{mg})$. The reaction was performed at $40{ }^{\circ} \mathrm{C}$ and $150 \mathrm{rpm}$.

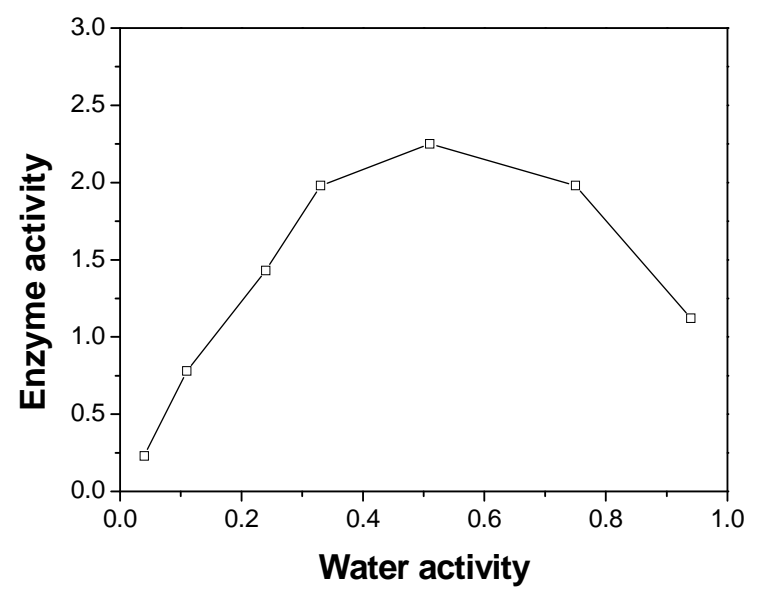

At low water activity, the conformation of PPL was excessively rigid, which might have disturbed the "induced-fit" process of PPL, and the enzyme activity was decreased [19]. At high $a_{\mathrm{w}}$ in organic solvents, the decrease in enzyme activity can be attributed to the excessively flexible conformation of lipase. The water in the reaction mixture may have acted as a competing nucleophile for the acyl-enzyme, thus suppressing the expected acyl transfer and causing an unfavorable equilibrium position in reversed hydrolysis. Hence, a high $a_{\mathrm{w}}$ had a negative effect on the thermodynamic balance, shifting the equilibrium towards hydrolysis [20].

\subsection{Effect of the Reaction Time}

It could be observed (Figure 4) that the produced triptorelin lactate increased with prolonged reaction time, and a yield of $30 \%$ for its ester could be achieved in about $48 \mathrm{~h}$ under optimum conditions.

Figure 4. Time course of the esterification of triptorelin with lactic acid catalyzed by PPL.

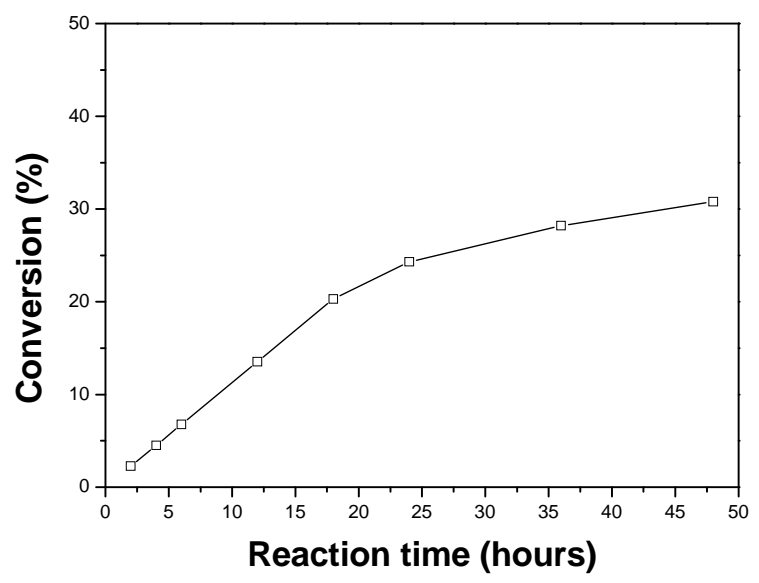




\section{Experimental Section}

\subsection{Catalysts and Chemicals}

Lipase from Pseudomonas sp. (PSL), Pseudomonas fluorescens lipase (Lipase AK, AKL) and Candida cylindracea A.Y. lipase (AYL) was purchased from Amano Pharmaceutical Co., Ltd. (Japan). Novozym 435 was purchased from Novo (Bagsvaerd, Denmark). Candida rugosa lipase (CRL) was purchased from Sigma (St. Louis, MO, USA). porcine pancreatic lipase (PPL) was purchased from Shanghai Dongfeng Biochemical Reagent Co., Ltd. (China). Octreotide acetate (purity > 99\%) was purchased from Shanghai TASH Biotechnology (China). Triptorelin was kindly donated by Wang Yingwu, Jilin University, China. L-lactic acid was purchased from Sigma-Aldrich Chemical Co. and was of analytical grade. Other regents were purchased from Shanghai Chemical Reagent Company (China). All the reagents and solvents were used without further purification.

\subsection{Water Activity $\left(a_{w}\right)$ Control and Measurement}

The used organic solvents were previously dried in a vacuum of $1 \mathrm{mmHg}$ for $12 \mathrm{~h}$. Then all the reaction mixtures with specific water activity $\left(a_{\mathrm{w}}\right)$ were prepared by adding a certain amount of water. The resulting samples were pre-equilibrated at the desired temperature for $24 \mathrm{~h}$ in a sealed vial before being subjected to $a_{\mathrm{w}}$ measurement. The water activity $\left(a_{\mathrm{w}}\right)$ was measured by Hygrolab Humidity Detector (Rotrnic, Swiss) before performing the reaction [21].

\subsection{Esterification of Triptorelin}

The reaction was performed by using triptorelin $(1.3 \mathrm{mg}, 1 \mu \mathrm{mol})$, lactic acid $(7.5 \mu \mathrm{L}, 100 \mu \mathrm{mol})$, benzene $(1.0 \mathrm{~mL})$, water activity $\left(a_{\mathrm{w}}=0.51\right)$ and lipase $(5.0 \mathrm{mg})$ while stirring at $40{ }^{\circ} \mathrm{C}$. To determine the concentrations of the produced ester, the organic samples were withdrawn from the reaction mixture and analyzed by high performance liquid chromatography (HPLC). The synthetic activity of enzyme $(\mu \mathrm{mol} / \mathrm{h} / \mathrm{g}$ ) was defined as the amount (in micromoles) of triptorelin ester produced per hour per gram of enzyme. Enzyme activity was determined while the conversion was controlled in the range of the 15\%-30\%. All experiments were repeated three times and the errors did not exceed $5 \%$. All graphs were based on the average values.

\subsection{Analytical Methods}

The concentration of the remaining peptide and the produced ester was analyzed by HPLC. After the completion of the reaction, the products were analyzed by a HPLC system (Agilent 1100), which consisted of a binary pump, an autosampler, an oven, and a Kromasil-C18 column (5 $\mu$ m, $150 \times 4.6 \mathrm{~mm}$ i.d.). Chromatography was performed at $25{ }^{\circ} \mathrm{C}$ with a $20 \mathrm{~min}$ linear gradient elution from $10 \%$ to $50 \%$ acetonitrile in water containing $1 \%$ TFA at a flow rate of $1.5 \mathrm{~mL} / \mathrm{min}$. Octreotide acetate (purity $>99 \%$ ) was used as internal standard. The products were detected at $280 \mathrm{~nm}$. Baseline separation of triptorelin and its lactate (11.7 and $12.0 \mathrm{~min}$, respectively) was obtained. Conversions were determined based on the peptide ester increase. 
We used an Agilent 1100-LC system (Agilent Technologies) coupled to a 6510-ESI TOF MS (Agilent Technologies). The molecular weight and amino acid sequence of triptorelin lactate were determined by electrospray ionization mass spectrometry (ESI-MS). The $y$ and $b$ series of fragment ions of triptorelin lactate were obtained by in-source collision-induced dissociation (CID) and the results were shown in Table 3 . The $m / z$ of triptorelin lactate was $1383.6(\mathrm{M}+\mathrm{H})^{+}$and the structure of triptorelin lactate was confirmed from the results of CID.

Table 3. $b$ and $y$ series ions of triptorelin lactate.

\begin{tabular}{|c|c|c|c|}
\hline $\begin{array}{l}\text { Fragment } \\
\text { ions }\end{array}$ & Structure & $\begin{array}{c}\text { Calculated } \\
\mathrm{m} / \mathrm{z} \\
\end{array}$ & $\begin{array}{c}\text { Measured } \\
\mathrm{m} / \mathrm{z}\end{array}$ \\
\hline b1 & Pyr & 112.04 & - \\
\hline b2 & Pyr-His & 249.10 & 249.1 \\
\hline b3 & Pyr-His-Trp & 435.18 & 435.1 \\
\hline b4 & Pyr-His-Trp-Ser(lactate) & 594.23 & 594.2 \\
\hline b5 & Pyr-His-Trp-Ser(lactate)-Tyr & 757.29 & - \\
\hline b6 & Pyr-His-Trp-Ser(lactate)-Tyr-D-Trp & 943.37 & 943.4 \\
\hline b7 & Pyr-His-Trp-Ser(lactate)-Tyr-D-Trp-Leu & 1056.46 & - \\
\hline b8 & Pyr-His-Trp-Ser(lactate)-Tyr-D-Trp-Leu-Arg & 1212.56 & 1212.6 \\
\hline b9 & Pyr-His-Trp-Ser(lactate)-Tyr-D-Trp-Leu-Arg-Pro & 1309.61 & - \\
\hline$(\mathrm{M}+\mathrm{H})^{+}$ & Pyr-His-Trp-Ser(lactate)-Tyr-D-Trp-Leu-Arg-Pro-Gly-NH & 1383.66 & 1383.6 \\
\hline y9 & His-Trp-Ser(lactate)-Tyr-D-Trp-Leu-Arg-Pro-Gly-NH ${ }_{2}$ & 1272.63 & - \\
\hline y8 & Trp-Ser(lactate)-Tyr-D-Trp-Leu-Arg-Pro-Gly-NH ${ }_{2}$ & 1135.57 & 1135.4 \\
\hline y7 & Ser(lactate)-Tyr-D-Trp-Leu-Arg-Pro-Gly-NH ${ }_{2}$ & 949.49 & 949.3 \\
\hline y6 & Tyr-D-Trp-Leu-Arg-Pro-Gly- $\mathrm{NH}_{2}$ & 790.44 & 790.3 \\
\hline y5 & D-Trp-Leu-Arg-Pro-Gly- $\mathrm{NH}_{2}$ & 627.37 & - \\
\hline y4 & Leu-Arg-Pro-Gly- $\mathrm{NH}_{2}$ & 441.29 & 441.2 \\
\hline y3 & Arg-Pro-Gly- $\mathrm{NH}_{2}$ & 328.21 & 328.1 \\
\hline y2 & Pro- Gly- $\mathrm{NH}_{2}$ & 172.11 & 172.1 \\
\hline y1 & Gly- $\mathrm{NH}_{2}$ & 75.03 & - \\
\hline
\end{tabular}

\section{Conclusions}

In conclusion, we describe here an effective method for the acylation of triptorelin by esterification in nonaqueous media, and PPL showed a higher catalytic performance. Under optimum conditions, the triptorelin lactate was successfully synthesized by catalyzation by PPL in benzene at $40{ }^{\circ} \mathrm{C}$ and $a_{\mathrm{w}}=0.51$, while lactic acid was used as acyl donor (the optimum molar ratio of lactic acid/triptorelin was 100:1). However, the activity was not satisfactory even under optimum conditions. Some techniques (for example, co-solvents, ultrasound and microwave irradiation) are currently in the process of being studied to further improve the properties of the enzyme and will be reported on in due course.

\section{Acknowledgments}

The authors are grateful for the financial support from National Natural Science Foundation of China (No. 21172093, 31070708 and 30870539). 


\section{References}

1. Fuchise, T.; Kishimura, H.; Yang, Z.H.; Kojoma, M.; Toyota, E.; Sekizaki, H. Atlantic cod trypsin-catalyzed peptide synthesis with inverse substrates as acyl donor components. Chem. Pharm. Bull. 2010, 58, 484-487.

2. Stevenson, C. Advances in peptide pharmaceuticals. Curr. Pharm. Biotechnol. 2009, 10, $122-137$.

3. Dahiya, R.; Mourya, R.; Agrawal, S.C. Synthesis and antimicrobial screening of peptidyl derivatives of bromocoumarins/methylimidazoles. Afr. J. Pharma. Pharmacol. 2010, 4, 214-225.

4. Lu, C.; Yu, X.; Huang, G.; Wang, H. Preparation and characterization of antigenic properties of gramicidin A-keyhole limpet hemocyanin and gramicidin A-ovalbumin conjugates. Afr. J. Biotechnol. 2009, 8, 7051-7058.

5. Pichereau, C.; Allary, C. Therapeutic peptides under the spotlight. Eur. Biopharm. Rev. 2005, Winter Issue, 88-91.

6. Cheng, W.; Lim, L.-Y. Comparison of reversible and nonreversible aqueous-soluble lipidized conjugates of salmon calcitonin. Mol. Pharm. 2008, 5, 610-621.

7. Wang, J.; Hogenkamp, D.J.; Tran, M.; Li, W.Y.; Yoshimura, R.F.; Johnstone, T.B.; Shen, W.C.; Gee, K.W. Reversible lipidization for the oral delivery of leu-enkephalin. J. Drug Target. 2006, $14,127-136$.

8. Guo, Z.W.; Machiya, K.; Salamonczyc, G.M.; Sih, C.J. Total synthesis of Bastadins 2, 3, and 6. J. Org. Chem. 1998, 63, 4269-4276.

9. Malnar, I.; Sih, C.J. Synthesis of the bis-diaryl ether fragment of vancomycin via enzymatic oxidative phenolic coupling. Tetrahedron Lett. 2000, 41, 1907-1911.

10. Malnar, I.; Sih, C.J. Chloroperoxidase-catalyzed chlorination of didechloroaglucovancomycin and vancomycin. J. Mol. Catal. B Enzym. 2000, 10, 545-549.

11. Breddam, K.; Widmer, F.; Johansen, J.T. Carboxypeptidase Y catalyzed $C$-terminal modifications of peptides. Carlsberg Res. Commun. 1981, 46, 121-128.

12. Shah, S.; Gupta, M.N. Lipase catalyzed preparation of biodiesel from jatropha oil in a solvent free system. Process Biochem. 2007, 42, 409-414.

13. Won, K.; Hong, J.K.; Kim, K.J.; Moon, S.J. Lipase catalyzed enantioselective esterification of racemic ibuprofen coupled with pervaporation. Process Biochem. 2006, 41, 264-269.

14. Wu, J.Y.; Liu, S.W. Influence of alcohol concentration on lipase catalyzed enantioselective esterification of racemic naproxen in isooctane: Under controlled water activity. Enzyme Microb. Technol. 2000, 26, 124-130.

15. Carrea, G.; Otto, L.G.; Riva, S. Role of solvents in the control of enzyme selectivity in organic media. Trends Biotechnol. 1995, 13, 63-70.

16. Gorman, L.A.S.; Dordick, J.S. Organic solvents strip water off enzymes. Biotechnol. Bioeng. 1992, 39, 392-397.

17. Serdakowski, A.L.; Dordick, J.S. Enzyme activation for organic solvents made easy. Trends Biotechnol. 2008, 26, 48-54.

18. Wehtje, E.; Costes, D.; Adlercreutz, P. Enantioselectivity of lipases: Effects of water activity. J. Mol. Catal. B Enzymatic 1997, 3, 221-230. 
19. Halling, P.J. Organic liquids and biocatalysts: Theory and practice. Trends Biotechnol. 1989, 7, $50-52$.

20. Ghamgui, H.; Karra-Chaabouni, M.; Bezzine, S.; Miled, N.; Gargouri, Y. Production of isoamyl acetate with immobilized Staphylococcus simulans lipase in a solvent-free system. Enzyme Microb. Technol. 2006, 38, 788-794.

21. Tian, R.; Yang, C.-H.; Wei, X.-F.; Xun, E.-N.; Wang, R.; Cao, S.-G.; Wang, Z.; Wang, L. Optimization of APE1547-catalyzed Enantioselective Esterification of $(R / S)$-2-methyl-1-butanol in an Ionic Liquid. Biotechnol. Bioprocess Eng. 2011, 16, 337-342.

(C) 2012 by the authors; licensee MDPI, Basel, Switzerland. This article is an open access article distributed under the terms and conditions of the Creative Commons Attribution license (http://creativecommons.org/licenses/by/3.0/). 